\title{
What Are the Strategies of Australia's Universities? Arenas, Vehicles, Differentiators, Staging and Economic Logic
}

\subsection{Arenas}

Figure 7.1 earlier suggests that each of Australia's universities is probably two enterprises - one for education and the other for research. Each university differs somewhat according to the range of arenas (faculties) over which it practises these activities. For most universities their mix of faculties seems to be the result of circumstance as much as a grand design. In contrast, in the post-war years when Stanford University started its rise to stardom, the decision was made to concentrate on postgraduate programmes (where national reputations were forged), and a relatively few areas where government funding signalled national importance-one of which was electronics research. The aim was to do a few things with distinction rather than 'creating excellent programs in fields no one cares about'. 1

A strategic decision that is very costly for a university is its choice of arenas. As just noted, Stanford chose some of these because the government of the day was prepared to underwrite much of the cost. If a university chooses to do world-class teaching and research in the natural and 
physical sciences, it can involve significant investments in infrastructure. In contrast, research in many fields of the humanities is far less costly.

The number, variety and size of arenas define the scope and academic footprint of a university. From a strategic perspective, when the logic guiding the choice of arenas is not clear it

- makes positioning the institution more complicated,

- increases the costs of administration (due to complexity) and

- complicates decisions about which areas to prioritise for funding.

A criticism of Australia's public universities is that their scope is too broad. To illustrate this point, consider the profiles in Fig. 9.1. Each circle represents an academic faculty scaled to size. Their relationship is depicted by their distance from each other. An issue we will raise in Chap. 11 is that each of Australia's universities looks more like Comprehensive University, one with a scattered academic footprint, than Focused University where the logic of its collection of faculties is more apparent. And if the numerous research centres and institutes that a comprehensive university has were added to Fig. 9.1, the picture would look much more complex.
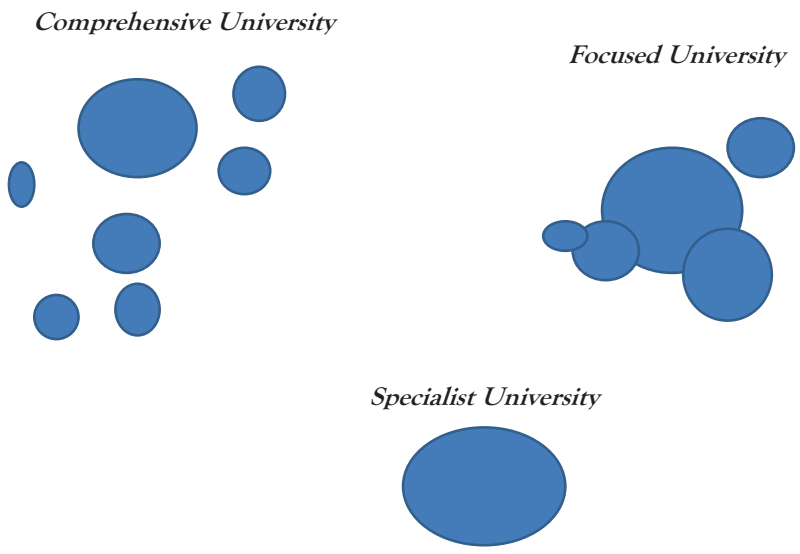

Fig. 9.1 Strategic scope 


\subsection{Vehicles}

The major vehicles used to codify education, such as the common range of degrees; deliver education, such as teaching philosophy, curriculum design, lectures, tutorials and web-based materials; assess learning, such as assignments and examinations; and do research, such as academic time and research equipment, are similar across all of Australia's universities. Thus from both a student and an academic perspective, 'going to university' means that they are joining a fairly well-defined type of institution and committing to a broadly similar experience. Yes, each university has some unique aspects, but universities have a high degree of 'sameness'. The Vietnamese have a saying that captures this situation:

Same, same, but different.

History and what is called isomorphism (imitation) create this sameness. This is the way that universities were organised in the past (history), and this is the way that a university's peers are currently organised, and so each tends to conform (isomorphism). Also, the rankings are designed to reflect this structure. So to look like a university, this is the dominant design. The value of this structuring of operations is that it clearly positions all universities as 'a university'. Stakeholders, both internal and external, are comfortable with this model. Consultants as we noted earlier suggest that it should be shattered.

It is interesting to delve deeper into the issue of sameness for two reasons. One is to expose the weakness of some consulting suggestions for change. At the present time many are simply infeasible. The other is to uncover the structural mechanisms that will impede any significant attempts to change.

\subsection{Differentiators}

Four institutional mechanisms cement the essential sameness of Australia's universities. The first is the overwhelming reliance on government funding. It is anchored to the Grand Bargain mentioned earlier, which comes 
with strings attached, namely, to be public institutions committed to the three traditional missions of teaching, research and community engagement. No university has the courage to publicly jettison any of these missions.

The second factor creating sameness is three powerful agencies. One is the Tertiary Education Quality and Standards Agency (TEQSA). Stemming from the Bradley Review of Australian Higher Education, this government regulator now imposes quality assurance mechanisms to set and review sector standards in the areas of teaching, learning, scholarship, research and research training. The second agency is the Australian Research Council's Excellence in Research Australia (ERA) programme. As noted earlier, this initiative produces an Australian university league table that encourages a degree of sameness of research across the universities by recognising discipline-based journal ranking lists which identify the set of de facto target journals for much university research. These are then used in the individual performance appraisal of staff. Thus, the requirements of these journals create the parameters for what is judged to be the type of research one should do and what quality means.

The third agency is the National Tertiary Education Union. This union negotiates the basic workplace agreements employed throughout the university system. While each university negotiates a different agreement with this powerful workforce union, they are very similar in structure and content. We would argue that these union agreements are designed more to protect the 'average' employee than to foster excellence across the system. One of their key conditions illustrates this opinion, namely, the duration of the paid working week. Currently this is typically 37.5 hours per week. For an academic 37.5 hours is far too short! It is impossible to be an excellent teacher and world-class researcher and then do some university service, and then some industry and community engagement by working 7.5 hours per day. So here is the problem:

- work 37.5 hours per week and do part of the job, or

- work 37.5 hours per week and do all the job at average quality or

- the university is deliberately underpaying its academic staff (and it should be taken to the Fair Work Commission). 
When one of us first joined the Australian university system, our terms and conditions of employment would easily fit a 37.5 hours per week. The employment contract was one page in length. It had three main paragraphs:

1. Welcome to the university.

2. Your level is $\mathrm{XYZ}$ and your pay is $\$ \mathrm{PQR}$ pa.

3. If you have any questions please talk to your Head of School.

In essence, the deal was 'you pretend to work and we will pretend to pay you'. There were no formal university expectations (regular performance appraisals), and some academic staff treated their employment as a form of paid social welfare. And yes, mediocrity was prevalent. In contrast, the last union-negotiated employment contract for one of us was 69 pages long. It was dense with terms and conditions of employment.

The third factor cementing sameness is the rise of NPM / professional management in universities. Much of this is directed at responding to the requirements of the TEQSA, the ERA and the legislation under which each university receives its charter. Also, there now seems to be a need to manage an ever-growing number of risks within the university environment, such as OH\&S, staff welfare, student welfare, student malpractice, research malpractice, cyber risk, data risk, ethical risk, operational risk, financial risk, regulatory risk, crisis risk, climate risk, reputation risk. Professional risk consultants have targeted universities to help them assess their vulnerability, design programmes to manage risk and recover from risk failures.

A rich and successful history plus these institutional mechanisms have combined to produce a higher-education sector with few meaningful differences. In commercial situations where there is an inherent sameness across members of a strategic group, such as the Big 4 Australian banks, one often observes artificial attempts to differentiate one institution from another. Corporate identity, branding and communication are often used for this purpose. The websites of the universities are revealing here. They are marketing devices. The first screen looks more like the package of a supermarket product than the front door to an organisation with a deep 
purpose. And from here they explode to reveal all the complexity of the institution's operations. At our last university there was a group of 28 administrators tasked with managing the institution's marketing and communications, and a further 36 responsible for brand strategy and engagement. As old marketers, we think that 64 people are not necessary to tell students about the university, especially when research suggests that many students get most of their information via WOM-word-ofmouth and word-of-mouse.

\section{$9.4 \quad$ Staging}

The strategic narratives of most universities suggest that they are constantly making changes to their operations to exploit opportunities and overcome obvious problems. Explore the website of any university and it is easy to find examples of new programmes being launched and new people being appointed to run such initiatives. There is no shortage of activity. For example, in the area of education each university seems to have adopted a different approach to learning. Their websites reveal learning philosophies like blended learning, block learning, flipped learning, group-based learning, case-study learning, student-led learning, workbased learning, problem-based learning, active learning, active and inquiry-based learning, flipped classrooms, design thinking, MOOCs and so forth. Long gone it seems is the era of 'chalk and talk'.

In the area of research while most activity still occurs within faculties, these endeavours have been supplemented with cooperative research centres, university and industry partnerships, and cross or multi-disciplinary research centres. The easiest way to explore new areas of interest seems to be to bolt-on a new research centre. The University of Western Australia's annual report notes it has 45 of these. From an NPM perspective these are an interesting idea because they allow the university's administrators to measure efficiency and performance. It is clear what they cost to run, what independent money they attract and what they produce. And because of their insular nature, they can be closed down if performance does not meet expectations. 
Another staging mechanism is the branch office. Some are local, such as a regional university with an office in the near-by capital city, and some are located in a foreign country, such as Dubai, Hong Kong, Singapore, Thailand, Vietnam. Many overseas universities have also followed this approach. All sorts of reasons are provided for why such endeavours are a good idea. However, many are not strategically sound. For example, some years ago both of us attended a meeting where the senior administration of the university suggested that a branch office of our school be opened in Hong Kong. The idea originated with an industry advisory group'Asia is booming, there are lots of students, why aren't you up there!' At the end of the meeting one old strategy professor (who was an exmanagement consultant) summed up the idea as follows:

As a small institution with limited financial resources let's be a late entrant into a highly competitive market where it is not clear about the regulatory requirements for accreditation; where some local universities are very good, and where recent overseas entrants like us are not making any money. And, to succeed we will have to redeploy from our current programs some of our best resources in order to establish our quality.

This comment was all it took to bring sanity back to the discussion. It was also a good example of the value of harsh academic scrutiny of the 'free advice' from people without deep knowledge of higher education and no skin in the game - the industry advisors were not willing to bankroll the venture.

On a number of occasions we have been critical of the lack of a clear line-of-sight between key aspects of strategy and the financial management of the university. While we were at the University of New South Wales, one of the vice chancellors (Fred Hilmer) made the effort to inform the senior academics about the revenues and costs of the university. At our last university this information appears in the annual business plan. Also, each university publishes a set of accounts in its annual report. Given that the annual report is a public document, we will use it to raise some important strategic issues in the next section. 


\subsection{The Economics of a University}

Chapter 1 noted that Australia's universities are happy to argue that they are under-funded. So a key question is whether this is true? A second question is whether our universities waste some of the funds they receive? Answers to both questions help to expose the Business Model and the Profit and Loss Statement of a university.

The University of South Australia is one of the few universities to discuss some of these factors. For example, by 2025 their plan is to:

- Grow the student body to 40,000, with $25 \%$ of these learning online. UniSA Online is the core asset that will support this (ad)venture.

- Generate $15 \%$ of their revenue from research activities, $60 \%$ of which will come from industry partnerships and $40 \%$ from research grants.

Now how will they grow student numbers and change the mix of research funding? Presumably, the student body will grow via the introduction of online courses. Hopefully it will not grow by lowering entry standards. So the first challenge is to make sure that these online courses do not cannibalise the revenue from their current courses. The second challenge is to do this without reducing quality. The third challenge is that they will have to compete against the online programmes of other universities in Australia and overseas. On the research front the idea is'By growing the scale and focus of research by building capacity in areas that have demonstrated excellence and shown potential for growth'. With a large budget this might be feasible, but do they have these funds? They don't say.

On the teaching front what puts grand plans like this at risk is price discounting. For example, there is an emerging trend for universities to offer substantial tuition fee discounts, especially to attract international students. Phil Honeywood, president of the International Education Association of Australia, said that many of these discounts were dressed up as scholarships. ${ }^{2}$ So, there is a downward pressure on fees-revenue. Competitors are just as desperate as UniSA to grow their numbers. 
On the research front UniSA is exposed by its lack of reputation. A quick look at the ERA rankings doesn't put the university in the top echelon, and as noted elsewhere, many Australian academics and their universities do not have a very good reputation for their commercial acumen. So while universities would like to generate more money from industry, many research academics simply don't care what industry wants. Getting favourable recognition from peers is far more important than getting research money from industrialists that is targeted to specific projects, and some of which the university may tax.

Because the economic logic of a university can be partly deciphered from its annual accounts, this is where we turn to next.

\subsection{The Funding Game: The Revenue Model}

At the 2018 Australian Financial Review Higher Education Summit, Anthony Walker, a director of sovereign and international finance ratings at S\&P Global, said that there is a game being played by the government and the universities. Because of budget pressures, the government wants to reduce its funding of universities while they want more funding, so the truth about what is an appropriate level of funding is likely to be somewhere in between. His analysis suggests that many universities have operating margins of between 8 and $10 \%$ and quite healthy cash flows. ${ }^{3}$ Yes, some universities might be in less than good financial health, but there is a moral hazard here-the government is highly unlikely to let one of them become insolvent. So, maybe the overall financial health of the universities is not as woeful as often claimed.

At this summit Philip Clark, a former federal government advisor on education, makes another point about the funding of the universities, namely that relying on the high numbers of overseas students, many of whom come from China, is a risky strategy. There are two financial risks here. One is that if overseas student revenue is used to 'balance the books', a downturn in demand puts the university's short-term revenue at risk. This was dramatically illustrated during the COVID-19 pandemic. The other is that if this revenue source is used to fund long-term investments in infrastructure or research, a downturn here puts these at risk. So, even 
though it is a luxury good in China to have an education from a Groupof-Eight university, if the Chinese government or other circumstances mean that these students stop coming to Australia, this revenue steam will stop very quickly. Also, an adverse change in the exchange rate or more restrictive student visa requirements quickly reduces the flow of international students.

Strategists like to look at what they call the revenue model of a business enterprise. In the university context, the focus is on the principal sources of revenue. To illustrate this, we will look at the 2017 Annual Report of the University of Western Australia (UWA). Here we see that UWA had $\$ 977$ million income for an underlying result (sustainable surplus) of \$18 million. Approximately $54 \%$ of this revenue was sourced from the Federal and Western Australian State Governments. Fees and charges were \$195 million (20\%), other income was $\$ 100$ million (10\%), research income was approximately $\$ 37$ million (4\%) and interest was $\$ 39$ million (4\%).

In summary, UWA is a big enterprise that relies for about half of its income from government funding, and it generates about one-third of its income from student fees. Hence, government relations, cost control and financial management are key skills. There is nothing surprising here. However, think about research. The reputation of the university is only strong enough to generate $4 \%$ of income from this source. This is the same amount generated by the investment committee of council. What these figures suggest is that the external demand for UWA research seems to be very small.

A little further digging through the annual report reveals another interesting observation. The university had 24,327 students of whom 14,791 were fee-paying undergraduates, and 7,587 were fee-paying coursework postgraduates. These students are serviced by five faculties (one of which is very small). One of the super-faculties comprised the cheap-to-run faculties, namely, arts, business, law and education. This group educates $51 \%$ of the university's undergraduates, $37 \%$ of coursework postgraduates and $23 \%$ of research postgraduates. This pattern suggests that this faculty is the cash cow for the rest of the university. It is like a giant ATM from which other parts of the university withdraw their weekly allowance. As a member of this super-faculty, you could feel 
proud-your efforts fund much of the rest of the university, or unappreciated-your efforts are unrecognised by others. Getting the economic mix of this core funding cross-subsidy game correct can make or break the finances of a university. It can also damage the reputation of the university if in a faculty like education, student entry standards are lowered to fill up the numbers. At the time of writing, this was a topic of conversation in the media.

When compared to the great universities in the USA, the piece of the revenue model that is largely missing from Australia's universities is its endowment. While there are many reasons that might account for the paucity of Australian university endowments, the stark fact is that these institutions do not have access to a significant amount of this revenue. Much of the money given to universities comes with constraints, such as to be used for a specific piece of infrastructure or type of research. And even sponsored academic positions, such as named chairs, are rare. As government funding becomes more constrained, the need for this type of income becomes greater. Imagine the opportunities that could be pursued by an Australian university with a couple of billion dollars in its war chest!

\section{The Cross-subsidy Game}

All Australian universities have a group of low-cost faculties and degreesthe cash cows that are used to fund the high-cost degrees-the stars. The star disciplines are generally the ones that underpin the major university reputation ranking systems. They are also the disciplines that tend to make the major scientific breakthroughs that get publicity on the nightly news and in television natural science documentaries. The deans of these disciplines are generally the most powerful academic voices inside the university. At UWA these are all sciences—science, health and medical sciences, engineering and mathematical sciences. Notwithstanding the economic significance of the cash cow faculty to UWA finances, in the annual report, the exploits of the sciences are given much more prominence than law, business and education.

Cross-subsidies lie at the heart of university growth. If an institution decides to grow by increasing the size of its high-cost faculties, it will 
generally have to generate more revenue from its less costly faculties. This can be done by enrolling more students, raising tuition fees, reducing the delivery costs of teaching and research or clawing back more of the current revenue from these faculties. However, if the institution grows only the less costly faculties, it has free cash flow to spend as it pleases. Thus, the economic modelling of these institutions is a critical component of strategy. This is seldom mentioned outside the executive suite.

Cross-subsidies, however, come at a price to reputation and social equity. Consider the following paradox — or as Ross Gittins, economics editor of the Sydney Morning Herald, calls it 'short-changing their students'. ${ }^{4}$ Step 1 is to attract students to cheap-to-provide occupational degrees - that have good job prospects like commerce, or a good image but fewer job prospects like law. Step 2 is to teach these undergraduates in large classes or substitute technology for face-to-face teaching. Step 3 is to agree to charge them a premium price. ${ }^{5}$ Step 4 is to use the free cash flow to pay the university administrators and cross-subsidise research and teaching in other areas. Now the paradox here is that even though our universities wish to project themselves as model social citizens, an unemployed or underemployed student from a cash cow faculty soon discovers that they have been sold a degree that is not worth as much as they thought. Just like most of their business counterparts, transparency is not generally one of a university's core values. In big business, and this is what our universities are, you keep your business model out of public view.

The alternative to cross-subsidy is internal privatisation. For example, some US and European universities have allowed their business schools to retain their revenue and pay only a minimal contribution to the rest of the university. As David Kirp describes for one US school, this allowed it to raise salaries and improve facilities while salaries were frozen and faculty needs were not met in other parts of the university. ${ }^{6}$ Any faculty with strong student demand and/or demand for its research could advocate for such a strategy. So from a strategic perspective, should a university allow any or some or all its faculties to 'privatise'? You will not find this strategic question discussed in any public statement. However, the pressure to (partially) privatise can be seen in the internal budgeting practices of the 
university. When universities adopt performance as opposed to activity budgets, it encourages their units to become (more) self-supporting. Chief financial officers argue that it brings more discipline to the budget process and greater internal transparency. Academics in smaller faculties might argue that it diminishes the overall contribution of the university. Vice chancellors need to make some tough strategic choices here.

\section{The R \& D Game}

Public universities by their nature have adopted an open, distributed model of research transfer through publishing research and educating people who then enter the workplace. While education provides revenue, publishing gives away much of the university's new knowledge to the publishing houses, which then sell it back to them (through subscriptions to their journals). To try to get some return from their research, some universities have entered the publishing game via their university press or by publishing a journal or two or three. If successful, both revenue and reputation flow back to the university. However, in Australia the more likely outcome is a university press that publishes short production runs and seeks not to put too much drain on the parent institution's finances.

The open model of research transfer puts a considerable strain on university finances. To help counter this, the universities now ask their academics to raise more of their own research funding. Securing Australian Research Council competitive research grants is highly prized, both for revenue and for reputation. However, this and other forms of funding come at a cost. The grant writing and peer-review process are very timeconsuming and highly problematic. They generate considerable amounts of stress for the people forced to seek these funds. And then when funds are secured, most academics need help navigating the university accounting, reporting and intellectual property policies.

At a National Press Club address Professor Ian Jacobs lamented about the underperforming state of business-university collaboration in Australia. His model is that the entire research pipeline moves from discovery, to translation, to application, to commercialisation. Our 
universities tend to focus on discovery, and industry on commercialisation. His strategy to help fill the gap was to ask government for more help in the form of things like better tax incentives for university-business projects, government co-investment in research projects and specific funding for translational research. The strategy here is to move down the value chain. Along these lines, in 2017 the British commercialisation company IP Group committed \$200 million to help some the Group-ofEight universities commercialise their research. ${ }^{7}$

Because this is such an important issue, it is worthwhile thinking about alternative models of research transfer and the roadblocks to such initiatives. The different initiatives respond to the different needs of organisations. Here are some further ideas.

\section{Engaging with Industry}

One was noted earlier in our description of working in the Australian Graduate School of Management. Business (and engineering) schools are closer to industry than many other faculties on a university campus. In the business school where industry collaboration was easiest to achieve, and where it seemed to have most impact, was when we were invited into a company to educate its managers. This generally involved customising our MBA course material to address a specific internal need. One crucial design element of many of these in-house courses was that the presenter would emphasise the role of evidence and research as inputs to management decisions. This was a good way to get research inside a company and to get decision-makers comfortable with using research in management practice. This is a good example of industry collaboration based on the perceived strength of the academic community (teaching). However, unlike the Harvard Business School we did not leverage this activity into writing case studies and selling them to other business schools. Our performance appraisal KPIs did not reward such 'clinical' activity. They do at Harvard.

A second approach is for the university to encourage and help its students to start their own enterprises, using what they have learned and discovered at university. This goes beyond offering courses in 
entrepreneurship. It requires a venture-capital approach to funding and mentoring new enterprise development. The idea here is for universities to formally invest in the new enterprises created by their students. The IP Group has also put $\$ 4.5$ million into Australian university research start-ups.

A third approach is for universities to promote to their researchers the benefits of working more closely with national laboratories (like the CSIRO), and government departments and agencies (like the Australian Institute of Sport). There are hundreds of these that span many areas of interest to the academic community. They also have their own funding that will support various types of research projects. These alliances are generally perceived as 'safer' than the next option.

A fourth approach is for the universities to develop strategic partnerships with key innovative companies. Old companies like Cisco, Exxon, General Electric, Hoechst A.G., IBM, Monsanto, Rolls-Royce and Siemens have collaborated with universities for years, and new companies like Amazon, Facebook and Google also work with universities. Because many companies adopt an open innovation approach to new product development, the basic research done in universities extends the workbench of both parties. ${ }^{8}$ The challenge is to get both parties to work together. What will often impede the development of a close working relationship is different goals, expectations and rewards of the parties and, more recently, squabbles over intellectual property rights. ${ }^{9}$

A fifth approach is to start a new academic hub. For example, the Australian National University has created its 3A Innovation Institute (Autonomy, Agency and Assurance) to create new applied science focused on managing the artificial intelligence and big data revolution. Many universities are 'playing' in this space with similar academic-industry collaborations. Many are also trying to entice students to join these initiatives by offering specialist (master's) degrees.

A sixth approach is to start or expand university consulting units. This type of work tends to focus more on problem solving than innovation. For example, the University of New South Wales has a professional enterprise called Unisearch that provides expert witness services. The University of South Australia has the Ehrenberg-Bass Institute for Marketing Science 
that collects money from companies to gather data on patterns of consumer behaviour, which are analysed to provide insights back to these companies. Other universities do sponsored research for specific industrial companies. While this is not without controversy, especially in some fields like pharmacy, in other fields like market research, there are fewer pitfalls. Where difficulties arise is when working with industry becomes transformative and some vocal staff claim that the institution's academic values may be compromised. Then contracts are required to provide confidence that conflicts can be managed, and leadership is required to endorse the principle that externally funded research is permissible and desirable.

A strategic advantage of building up industry engagement is that it often provides insight into future research opportunities. Thus, engagement becomes a dynamic capability focused on sensing research opportunities and seizing other-peoples' money to explore these issues. In the USA one of the biggest sources of funding for such future-oriented research is the military.

From a goal-setting and incentive point of view, industry engagement activities need to align with university and individual key performance indicators. Three current metrics are funding, impact and engagement. So research that is of interest to industry can secure new funding. Then to create impact, the university and its research teams need to add an advocacy element to their research. This can be done by a public relations effort to explain who needs to know about the research and what policy is necessary to implement the findings. Finally, engagement can be facilitated by the research team 'consulting' with the parties who will use the research findings. They help organisations use the findings to solve their problems. Research funding without specific advocacy and engagement often falls short of its promise.

\section{Roadblocks}

While all these initiatives could be helpful, they don't address some of the key reasons why too few academics work directly with industry and why many business enterprises are somewhat reluctant to work with academics and their universities. Here are some roadblocks that need to be addressed before a university's goal of significantly greater industryuniversity collaboration is likely to be met: 
- We don't understand each other: Business often find it difficult to identify if a university has any knowledge of interest to them. Research academics have their own interests that may or may not have any practical implications. So the base condition for both parties is to politely ignore each other.

- Training and focus: Doing a PhD can be a brutal process that imprints a certain way and timescale for doing research. Also, the motivation for doing this piece of research is often grounded in the existing scholarly literature rather than in the field of practice. So in many disciplines $\mathrm{PhD}$ students follow the university mission outlined earlier by Brian Schmidt, namely, they want to add to the stock of knowledge rather than solve a problem that is troubling industry.

- Because approximately 50\% of new PhD graduates now enter industry, various programmes have been designed to help these graduates migrate to a non-university workforce. For example, the APR.Intern programme focuses on getting students internships across all sectors of industry. What both employers and graduates are finding is that doctoral training provides many transferable skills that enhance workplace performance. ${ }^{10}$ However, many of these skills often need some reshaping before they 'work' in the workplace.

- In academic performance appraisals, working with industry tends to rate behind research publications in the top-rated journals. Also, few of these journals focus on industry problems. And excellent teaching evaluations are often not related to industry engagement. So if universities really want their academics to work more with industry partners, they might consider rewriting the contracts of some chosen academics. The Harvard Business School case noted earlier has solved this problem.

- Taxing industry funding: In order to pay for overheads, there are a number of ways in which universities can 'tax' research money from outside sources. Hence, from the point of view of the patron, not all their money goes to the nominated research topic. This can detract from the perceived value of their contribution.

- Academic reputations: In Australia many academics have a reputation for being not very commercially astute. They live and work 'in an ivory 
tower'. Their research is 'just academic'. They are too slow. Doing linkage research with an industry partner is too bureaucratic. And so the list goes on. So many Australian academics are handicapped by their reputation and that of their parent university. Many organisations would rather seek help from dedicated research institutions like the CSIRO or hire a freshly minted PhD who has not been too 'corrupted' by the academic environment. In many cases what makes academic research so powerful is also what makes it less than timely in a commercial setting. Good research especially big-bang breakthroughs, takes time and is plagued by missteps, things that industry can't easily accommodate.

- Track record: Over many years we have seen repeated intellectual failures across many sciences. Recent memorable examples are (a) the failure of (financial) economists to predict the global financial crisis, and once it was underway, to recommend ways to fix it, and (b) the failure of political scientists to predict the election of Donald Trump to the US White House, and that British citizens would vote to leave the European Union (Brexit). If academics can't provide clear insight into episodes such as these, why should we expect industry to rush to collaborate with universities?

So if open research transfer is laudable but expensive, and industry collaboration is somewhat problematic, there is a lot of work to be done before industry will come rushing to seek help from Australia's universities. Yes, there will be ad hoc pockets of success, but universities need to take a realistic look at their strategic and financial goals for this activity.

\subsection{The Funding Game: The Cost Model}

Like every large organisation universities have a diverse cost base. However, a quick look at the University of Western Australia's (UWA) annual financial statements reveals that the biggest cost is people. About $60 \%$ of total expenditure is classified as 'employee-related expenses'. 
Earlier we noted that many, if not most, Australian universities have at least as many, if not more, administrative staff than academics. In 2017 the UWA staff numbers were:

- $42.9 \%$ in non-academic units

- $10.7 \%$ professional staff in academic units

- $5 \%$ professional research staff

- $16.2 \%$ research only academics

- $3.3 \%$ teaching only academics

- $21.7 \%$ teaching and research academics

- $0.2 \%$ academic other staff.

So the people in administrative roles outnumber the front-line academics (42.9-41.2\%). ${ }^{11}$ This situation is slightly more in favour of the administrators if we add some of the $10.7 \%$ of professional staff in the academic units to the administration count. These percentages reveal direct administrative costs. But it gets worse. Because nearly every academic will be involved in some form of faculty administration, then part of their salary should also be allocated to the total university administration cost. For example, in 2015 in the University of Sydney there were more than 150 faculty committees involved in administration. ${ }^{12}$

Another interesting picture emerges if we look at non-salary costs. For example, in 2017 the non-salary budget was just under $\$ 244$ million. Then add to this - student expenses of $\$ 48$ million, materials and supplies of $\$ 28$ million, repairs and maintenance of $\$ 22$ million, finance costs of $\$ 6$ million and other expenses of $\$ 131$ million and we get a total of $\$ 479$ million before a single class is taught or a single research paper published. ${ }^{13}$ This is a lot of money to run a medium-size university. Most other Australian universities look similar.

\section{Compliance Costs}

Multinational corporations and other large organisations spend millions of dollars and millions of hours of employee time each year on compliance. The belief is that rigorous compliance programmes reduce the motivation for employee wrongdoing. Also, if an employee does 
something wrong, the regulator and the institution's insurance provider will note that at least the organisation actively tried to avoid such a problem. The aims of these programmes are (a) to get employees to behave ethically and adhere to best practice, and (b) to eliminate the time-consuming and distracting regulatory and legal processes that accompany regulatory failure. But as is all too evident, these programmes don't always stop employee wrongdoing. An aggressive organisational culture and financial incentives will often drown out compliance training, especially when meeting stretch goals determine salary and promotion. For example, there are still periodic cases of administration (admissions scandals), academic (falsifying research) and student (cheating) misconduct.

All universities require that their staff do compliance training. For an administrator this is part of what they are paid to do. However, for a student or an academic it is not clear what compliance training crowds out of the daily agenda. For example, as most academics will acknowledge, teaching crowds out research and service. Anything to do with delivering or administering a course will take priority over other activities, even sometimes one's family. However, what comes next in the priority list depends on who asks for help. In the latter part of our academic careers, we have seen the people in central administration jump up the priority list, not by asking for help, but by demanding compliance. For example, this occurs when say a new teaching or reporting protocol is launched and everybody has to make changes to what they were doing previously.

Another example of a compliance cost was noted earlier. Recall that the University of Technology Sydney requires training for all staff on issues such as equal opportunity, mental health awareness, privacy essentials, communication and collaboration, consent (unwanted sexual behaviour), health and safety, legal affairs, preventing bullying and safety and well-being. At the time of writing, the consent training was being pushed throughout the university-for all staff and all students. It was mandatory for everybody. The online course took approximately one hour to complete and required a $100 \%$ pass on the quiz that followed the training module. Students were threatened with the withholding of their grades if they did not successfully complete the course; casual 
academics were offered one hours' worth of salary for their participation, and old professors were sent escalating emails (first by the HR system, then the head of school, then the dean of the business school, then the vice chancellor) when the system reported that they had not completed the course.

Leaving aside the legal and moral issues of such a request, the costs of this programme can be estimated as follows. From the university website we see that there were

- 44,887 students (which include 14,289 international students) $\times 1$ hour $=44,887$ hours of unpaid time.

- 3631 full-time equivalent staff $\times 1$ hour $=3631$ hours of paid time.

Now if we take an hourly rate of $\$ 50$, we see that this exercise has cost the university more than $\$ 180,000$ for staff. ${ }^{14}$ And at, say, a notional $\$ 20$ per hour for the students, it also has a cost of $\$ 897,740$ for the students (minus one hour of their study time). So here is an administrative initiative with about a $\$ 1$ million price tag. All this to address a social issue that the senior administrators in the university thought would signal the institution's commitment to social justice. To cover themselves, they sought legal advice before embarking on this course of action.

There is an important ethical issue here. Imagine the cost to a finalyear student who can't get a job because there is an embargo on their grades because they did not complete and pass a non-curriculum course on a social issue for an organisation that they are about to leave. Second, there is no research that supports the claim that sexual harassment training actually works. ${ }^{15}$ So here we see the university imposing a dead-weight economic cost on the institution and a dead-weight social cost on some of its members. ${ }^{16}$

Another largely hidden cost in our universities is due to quality assurance programmes. They are used to signal institutional quality. For example, there are a number of organisations that have developed best practice protocols for education. These organisations promote their programmes, and once a couple of institutions 'sign on', they chase other similar universities to 'catch up'. Many university faculties sign onto such 
programmes with little evidence that they work and without due consideration for the total compliance costs. For example, the business schools of many of Australia's universities have signed up to various accreditation programmes. The University of New South Wales business school advertises its membership of two such accrediting bodies, namely, the AACSB (Association to Advance Collegiate Schools of Business) and EQUIS (European Foundation for Management Development). ${ }^{17}$ The school pays to join, pays to be certified and pays to be recertified every few years. Inside the business school, degree programmes need to be (re)shaped to fulfil the accrediting scheme's standards and someone is tasked with checking compliance. Then information has to be collected to report compliance each period. The costs easily accumulate into the hundreds of thousands of dollars for each such certification. However, there is little empirical evidence to suggest that these sorts of accreditation lead to more effective or efficient education, that they attract more students or that they allow the institution to charge higher course fees-especially when all competitors have signed onto the same programmes. However, what these programmes do is to lead to a lack of differentiation across the schools who sign on.

All of Australia's universities are plagued with hidden compliance costs. The key question is whether they deliver noticeably better outcomes.

\section{IT Costs}

One of the great paradoxes of modern times is that as information technology has advanced in leaps and bounds, it is much harder to find if these advances have had a general effect on increasing productivity. Within the university context, the productivity gains from new technology have been patchy. Many gains are the result of faster communication between people rather than better communication. But as the overuse of social media has demonstrated, new or upgraded information technology doesn't necessarily lead to better outcomes.

On a university-wide basis, many of the changes in technology are introduced because the suppliers of a platform have upgraded their offer. So the university 'keeps up to date' by adopting the latest version. 
However, the benefits of these upgrades are seldom realistically estimated relative to the compliance costs of requiring thousands of staff, and students make changes to accommodate the new system. Hence, an upgrade usually causes some pockets of frustration and costly time in compliance, especially for the people who are not as IT proficient as their colleagues. Universities could save hundreds of thousands of dollars in cost if they had more staff and student input into what really needs to be upgraded as opposed to being 'led' by their suppliers.

\subsection{The Big Question}

Is the Australian taxpayer getting good value for money from its public universities? If a typical university like the University of Western Australia costs hundreds of millions of dollars annually before it produces a single key output, is this money well spent? And if not, where might cost savings be found?

These are difficult questions. And because universities know more about universities than governments or the media, the universities are best placed to provide the answers. Our analysis suggests that the problem is of two parts, namely, that the strategies of the institutions are underdeveloped and thus complexity and coordination costs accumulate. The other related cost is that the institutions become overstaffed and too bureaucratic. So one strategy for the government is to tighten up its funding and make each university find its own solution. Universities would do well to avoid this brute-force solution by seeking greater efficiency and effectiveness in their operations.

\section{Notes}

1. As noted in S. Leih and D. Teece, "Campus Leadership and the Entrepreneurial University: A Dynamic Capabilities Perspective", Academy of Management Perspectives, Vol. 30, No. 2 (2016), p. 194.

2. Quoted in S. Powell, "Discounts catch on as international lure", The Australian (5 September, 2018), p. 29. 
3. E. Tadros, "Unis banking upside to defy funding cuts and lift margins', Australian Financial Review (30 August, 2018), p. 8.

4. R. Gittins, "We've turned our unis into aimless, money-grubbing exploiters of students", Sydney Morning Herald (17 September, 2017).

5. For example, while a degree in medicine costs much more than a degree in commerce (at the time of writing, this was $\$ 33,405 \mathrm{~V} \$ 12,658$ ), the student contribution in both degrees was the same $(\$ 10,596)$.

6. D. L. Kirp, Shakespeare, Einstein, and the Bottom Line (Cambridge and London: Harvard University Press, 2003).

7. As reported in T. Dodd, "Down payment made on $\$ 200 \mathrm{~m}$ start-up bet", The Australian (29 May, 2019), p. 26.

8. See, for example, M. Perkmann and A. Slater, "How to Create Productive Partnerships with Universities", MIT Sloan Management Review, Summer (2012), 79-88.

9. See for example, L. Frølund, F. Murray and M. Riedel, "Developing Successful Strategic Partnerships with Universities", MIT Sloan Management Review, Winter (2018), 71-79.

10. P. X. McCarthy and M. Wienk, "Advancing Australia’s Knowledge Economy: Who are the Top PhD Employers?" Australian Mathematical Sciences Institute \& CSIRO, May, 2019).

11. A note to the annual financial statements indicates that this group's salary is slightly less than that of the academics.

12. As reported in University of Sydney, Improving Our Organizational Design, Strategic Planning for 2016-2020, Discussion Paper No. 16 (September, 2015), (page 10).

13. Some people might want to add $\$ 54$ million of asset depreciation, amortisation and impairment to this figure.

14. At this time, the pay rate for the casual staff was either $\$ 46.60$ or $\$ 55.73$ per hour (depending on their qualification). Because academic staff is paid more than this, the estimate here is low.

15. "While sexual harassment training is the most traditional approach to preventing sexual harassment, it has not been shown to do so." This statement is from-Consensus Study Report of the National Academies of Sciences, Engineering and Medicine, reported in P. A. Johnson, S. E. Widnell and F. F. Benya (Eds.), Sexual Harassment of Women (Washington, DC: The National Academies Press, 2018), p. 150. 
16. Towards the end of 2018 a report to the council revealed that many students found that the course was inappropriate to their concerns and that many had yet to complete it. So teaching staff were asked to remind the students that their grades would be withheld!

17. For example, on the UNSW website you can't find what the letters AACSB actually stand for. You have to go to the association website and then search beyond the first page to find what they stand for. So how can these five letters really affect the decision-making of a new student if they are essentially meaningless? 